\title{
EXPERIMENTAL INVESTIGATIONS ON PERFORMANCE OF MIXTURE OF JATROPHA AND CASTOR BIODIESELS AS ALTERNATIVE FUEL FOR DIESEL ENGINES
}

\author{
Degaga Petros Areru \\ Departement of Agricultural Engineering, \\ Ambo University Institute of Technology, \\ Ambo, Ethiopia
}

\begin{abstract}
This study have been investigated the performance of the mixture of Jatropha and Castor biodiesels with the conventional diesel fuel in diesel engine. The four cylinder, four strokes cycle, water cooled, direct injection engine of rear wheel derived vehicle was used for the experiments. The blend were prepared as B0 (petro diesel), B20 JB (Jatropha biodiesel blend), B20 CB (Castor biodiesel blend), and B20 JCB (Jatropha and Castor biodiesel blend) for the comparison. The result investigated that mixing of biodiesel from Jatropha and Castor oil were used to improve the high viscosity and density of castor biodiesel, and to provide better cold weather operation of Jatropha biodiesel. From the performance test results, the mixture of Jatropha and Castor biodiesel blend (B20 JCB) shows 3.06\% and 3.37\% reduction of brake power and brake torque compared to pure diesel (B0), respectively. The average brake specific fuel consumption of $\mathrm{B} 20 \mathrm{JCB}$ was increased by $4.89 \%$ compared to the pure diesel. Generally, from the experimental investigations the mixture of Jatropha and Castor biodiesel blend can be used as an alternative source of fuel in the future.
\end{abstract}

Key words: Biodiesel, Jatropha, Castor, diesel engine, brake power, brake torque, brake specific fuel consumption.

\section{INTRODUCTION}

Biodiesel is defined as mono-alkyl esters of long chain fatty acids derived from renewable biolipids via transesterification process, which conform to ASTM D6751 specifications for use in diesel engines [2]. Biodiesel is made from natural, renewable sources such as new/used vegetable oils and animal fats [1]. It is commonly prepared by transesterification reaction of vegetable oil with low molecular weight alcohol, such as ethanol or methanol [3]. The properties of biodiesel generally has higher density, viscos-ity, cloud point, cetane number, lower volatility and heating value compared to diesel fuel that affecting on the engine performance and emissions. However, neat biodiesel or its blends may be used in the existing diesel engines with little or no modification to the engine [4], [5].

From the literatures, several works on the consumption of biodiesel and its blends in diesel engines have been performed. The researchers are focused on single biodiesel like
Soybean oil, Rapeseed oil, Pongamia pinnata oil, Cotton seed oil, Neem oil, Castor oil, Mahua oil, Jatropha oil, Linseed oil, Rice bran oil etc., and its blends with diesel [6-17]. The researchers left a gap for the combination of dual biodiesels (mixtures of two different biodiesel).

From previous studies, it is evident that single biodiesel offer acceptable engine performance and emissions for diesel engine operation. Very few works have been conducted with the combination of diesel and two different biodiesel as an alternative fuel. But the unrevealed concept of two biodiesels [18-21], really applies to diesel engines instead of the single biodiesel and producer gas/ ethanol. The performance of the mixture of Jatropha and Castor biodiesel blend was not found in previous works. The aim of this study is to evaluate the performance characteristics of the mixture of Jatropha and Castor biodiesel blended with diesel in diesel engine.

\section{MATERIALS AND METHODS}

\section{A. Extraction of Jatropha and Castor oil}

The Jatropha and Castor seed were obtained from Melkassa Agricultural Research Center, Ethiopia. The method used to extract the Jatropha oil was mechanical pressing of the Jatropha seed by a human operated hydraulic pressing machine which was available in the work shop of Melkassa Agricultural Research Center, Ethiopia.

The Castor oil was obtained by mechanical pressing of the Castor seed by a human operated hydraulic pressing machine which was developed by the Bako Agricultural Engineering Research Center, Ethiopia.

\section{B. Laboratory Preparation of Biodiesel}

The transesterification reaction of Jatropha oil was carried out at Melkassa Agricultural Research Center, Food and Nutritional Department laboratory. While the transesterification of Castor oil was carried out at Adama Science and Technology University, Chemistry department laboratory.

Preheating of Castor and Jatropha oil was comprised by heating $500 \mathrm{ml}$ of oil at $120^{\circ} \mathrm{c}$ for 30 minutes. Then the Jatropha oil was cooled down to $60^{\circ} \mathrm{c}$ while Castor oil was cooled down to $35^{\circ} \mathrm{c}$ and the oils were ready for transesterification reaction.

Transesterification of Castor and Jatropha oil was done by dissolving $5 \mathrm{gm}$ of $\mathrm{KoH}$ (i.e., catalyst concentration of $1 \%$ ) 


\section{International Journal of Engineering Applied Sciences and Technology, 2019 \\ Vol. 4, Issue 3, ISSN No. 2455-2143, Pages 75-80 \\ Published Online July 2019 in IJEAST (http://www.ijeast.com)}

in $250 \mathrm{ml}$ of methyl alcohol (i.e., mole ratio of oil to methanol of 1: 6). The potassium methoxide solution was then poured into the warm oil (i.e., at $60^{\circ} \mathrm{c}$ of Jatropha and at $35^{\circ} \mathrm{c}$ of Castor oil) and stirred vigorously (for 40 minutes for Jatropha and 60 minutes for Castor) using a magnetic stirrer. The mixture was then allowed to settle for 24 hours in a separating funnel to separate glycerol from methyl ester (Fig.1).

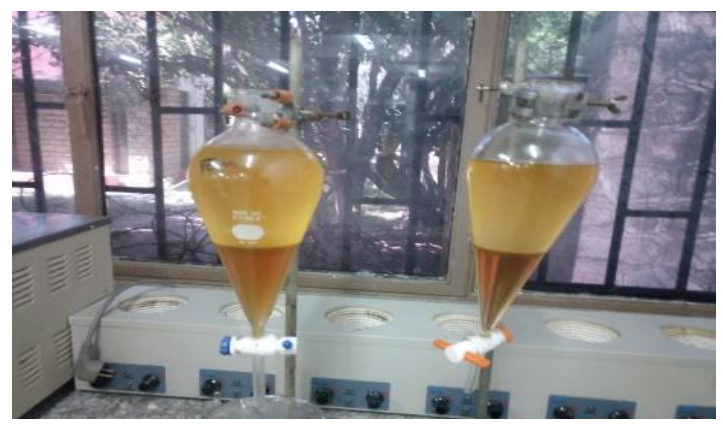

(a) Jatropha

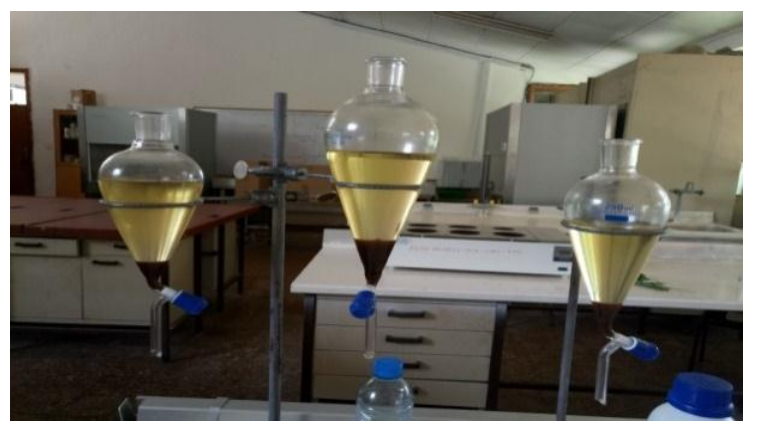

(b) Castor

Fig.1. Separation of the glycerol

The biodiesel was then poured into a separate beaker, while the lower layer (which comprises of glycerol and soap) was collected from the bottom of the separating funnel. Warm water $(30 \% \mathrm{v} / \mathrm{v})$ was then used to wash the biodiesel to remove any excess glycerol and soap that remain in the funnel. The washed sample was dried by placing it on a hot plate for $1 \mathrm{hr}$ at $120^{\circ} \mathrm{c}$ for Castor biodiesel and in oven for $2 \mathrm{hr}$ at $110^{\circ} \mathrm{c}$ for Jatropha biodiesel. Then the quantity of biodiesel collected was measured and yield of biodiesel was calculated.

\section{Characterization of Biodiesel}

In this study characterization of biodiesel was done in partial that is only for density, viscosity, flash point and cloud point at Ethiopian Petroleum Supply Enterprise Laboratory and the test was done as per the procedure of the enterprise in reference to ASTM methods with no involvement of the researcher. The sample drawn for characterization was only Jatropha biodiesel (B100 JB), Castor biodiesel (B100CB) and mixture of Jatropha and Castor biodiesel (50\% Jatropha and 50\% Castor) or B50JB50CB.

\section{Biodiesel Blend Preparation}

Biodiesel can be blended with petrol diesel in any proportion, with B5 (5\% biodiesel and 95\% diesel) and B20 ( $20 \%$ biodiesel and $80 \%$ diesel) being the most common.
No vehicle alternations are necessary if blended at levels of B20 or lower, although original equipment manufacturers have varying policies approving different blends for use in their vehicles. In this study B20 (20\% biodiesel and $80 \%$ diesel fuel) was being used in a conventional CI engine for the comparison. These are pure diesel (B0), Jatropha biodiesel blends (B20 JB), Castor biodiesel blends (B20 $\mathrm{CB}$ ) and mixture of Jatropha and Castor biodiesel blends (B20 JCB). Fuel blends were prepared by volume as shown in the table -1 below.

Table -1: Blend Proportions of Test Fuels.

\begin{tabular}{|l|l|l|l|l|}
\hline $\begin{array}{l}\text { Fuel } \\
\text { type }\end{array}$ & $\begin{array}{l}\text { Petro } \\
\text { diesel }\end{array}$ & $\begin{array}{l}\text { Jatropha } \\
\text { biodiesel }\end{array}$ & $\begin{array}{l}\text { Castor } \\
\text { biodies } \\
\text { el }\end{array}$ & Total \\
\hline $\mathrm{B}_{0}$ & $2000 \mathrm{ml}$ & - & - & $2000 \mathrm{ml}$ \\
\hline $\mathrm{B}_{20} \mathrm{JB}$ & $1600 \mathrm{ml}$ & $400 \mathrm{ml}$ & - & $2000 \mathrm{ml}$ \\
\hline $\mathrm{B}_{20} \mathrm{CB}$ & $1600 \mathrm{ml}$ & - & $400 \mathrm{ml}$ & $2000 \mathrm{ml}$ \\
\hline $\begin{array}{l}\mathrm{B}_{20} \\
\mathrm{JCB}\end{array}$ & $1600 \mathrm{ml}$ & $200 \mathrm{ml}$ & $200 \mathrm{ml}$ & $2000 \mathrm{ml}$ \\
\hline
\end{tabular}

\section{E. Experimental Test Set up for Performance Testing}

The performance test was conducted at the Mechanical and Vehicle Engineering work shop of Adama Science and Technology University. Vehicle performance was measured in terms of tractive effort and wheel power. The chassis dynamometer was used to measure these tractive effort and wheel power.

Figure 2 shows a schematic of the rolling road test set up. A Sun ROAD-MATIC chassis dynamometer was used for measurement of power, tractive effort and road speed. A cooling fan (blower) was placed in front of the vehicle radiator to provide sufficient cooling to the vehicle. Speed was controlled by the operator using dynamometer load switch.

The measurement time is about 10 seconds of the full load (for the stabilization of speed and result reading) for each measurement point (an individual value of speed). Data was measured at test speed selected with $5 \mathrm{~km} / \mathrm{hr}$ intervals starting from $25 \mathrm{~km} / \mathrm{hr}$ to $75 \mathrm{Km} / \mathrm{hr}$. The experiment was conducted in first gear, second gear, third gear and fourth gear.

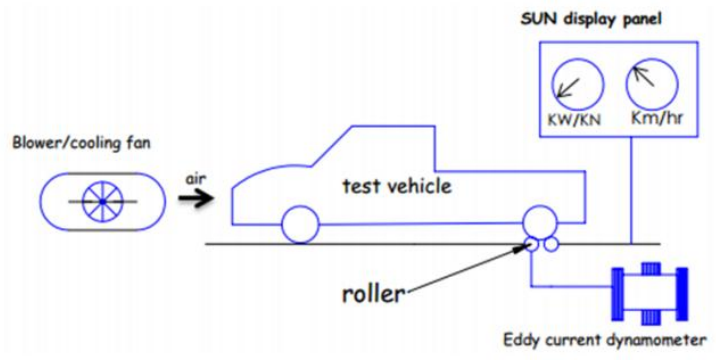

Fig.2. Schematic of test set up used for vehicle mounted on the rolling road.

The test was start with pure diesel fuel (B0) and followed by the B20 JB, B20 JCB, and B20 CB. For accuracy of the measurement the test was repeated three times for each tested fuel samples. The amount of the fuel consumed by an engine was measured by Thepra quantity measuring device. 
This device was used to measure the volumetric flow rate of the fuel flow.

Table -2: Engine and Vehicle specifications

\begin{tabular}{|l|l|}
\hline Engine model & $3 \mathrm{~L}$ \\
\hline Maximum power & $67 \mathrm{KW} @ 4000 \mathrm{rpm}$ \\
\hline Displacement & $2779 \mathrm{cc}$ \\
\hline Compression ratios & 22.2 \\
\hline Maximum torque & $188 \mathrm{Nm} @ 2400 \mathrm{RPM}$ \\
\hline Tire size & $215 \mathrm{R} 15-6$ \\
\hline
\end{tabular}

\section{F. Data Analysis}

From the experiment, wheel power and tractive effort data were directly collected from chassis dynamometer. These data were obtained in accordance with specified vehicle speed and should have to be converted into brake power and brake torque of the engine relative to the engine speed to get the performance of the engine. Also the fuel flow rate was directly obtained at different vehicle speed. This flow rate has to been converted to brake specific fuel consumption relative to the engine speed.

\section{RESULTS AND DISCUSSIONS}

\section{A. Extraction of Jatropha and Castor oil}

The machine extracts about $25 \%(\mathrm{~m} / \mathrm{m}$ ratio) of Jatropha oil (i.e. from $20 \mathrm{~kg}$ Jatropha seed $5 \mathrm{~kg}$ oil were obtained) and $29.2 \%(\mathrm{~m} / \mathrm{m}$ ratio) of Castor oil (i.e. from $12 \mathrm{Kg}$ of castor seed $3.5 \mathrm{~kg}$ of oils were obtained) from the seed sample.

\section{$B$. Biodiesel Yield}

The biodiesel production was done by transestrification reaction process using methanol alcohol and $\mathrm{KOH}$ catalyst. After washing three times by distilled water and drying the biodiesel production yield is found to be $80 \%$ and $84 \%$ for Jatropha and Castor, respectively.

\section{Characterization Result}

The characterization results of the biodiesel produced from Jatropha and Castor seed oil and their mixture were shown in the table -3 below. From the table -3 , the density of Jatropha biodiesel was lower than that of castor biodiesel. The density observed by Jatropha biodiesel was within the range given by European standard (EN 14214). The viscosity of Jatropha biodiesel was somewhat higher than of the ASTM standard. This may due to the absence of acid pretreatment to reduce the free fatty acid content of the oil before the transesterification. But the viscosity result was correlated with the result observed by Mengesha Kassahun, B. et al. (2016) or [22]. Compared to the Jatropha biodiesel the viscosity of castor biodiesel is higher. The high viscosity and high density of castor biodiesel was due to the presence of recionelic acid. Castor biodiesel had lower cloud point than Jatropha biodiesel, making castor biodiesel more suited for use in cold countries than Jatropha biodiesel. But the biodiesel blends of Castor oil with Jatropha cause to the improvement for the operation in cold weather. Flash points of the Castor and Jatropha biodiesels were within the standard. Compared to the castor biodiesel the blend of Jatropha and Castor biodiesel gives the less viscosity and lower density. The flash point of their blend was within the standard. Since the fuel with the flash point more than $66^{\circ} \mathrm{c}$ is considered as a safe, the results of all samples of bio-diesels are considered to be safe to store and to use in the engine.

Table -3: The properties of Biodiesel Produced

\begin{tabular}{|c|c|c|c|c|c|c|c|}
\hline \multirow[t]{2}{*}{ SN. } & \multirow[t]{2}{*}{ Property } & \multirow{2}{*}{$\begin{array}{l}\text { Test } \\
\text { method } \\
\text { ASTM }\end{array}$} & \multirow{2}{*}{$\begin{array}{l}\text { EPSE } \\
\text { diesel } \\
\text { limits }\end{array}$} & \multirow{2}{*}{$\begin{array}{l}\text { ASTM } \\
\text { D6751* } \\
\text { limit for } \\
\text { B100 }\end{array}$} & \multicolumn{3}{|c|}{ Test results } \\
\hline & & & & & B100 CB & B100 JB & $\begin{array}{l}\text { B } 100 \text { of } \\
50 \% \mathrm{CB} \\
+50 \% \mathrm{JB}\end{array}$ \\
\hline \multirow[t]{2}{*}{1} & Density@15 $15^{\circ}, \mathrm{g} / \mathrm{ml}$ & D4052 & Report & - & 0.9284 & 0.8900 & 0.9084 \\
\hline & Density@20ㄷ, g/ml & D4052 & Report & - & 0.9251 & 0.8865 & 0.9050 \\
\hline 2 & Flash point, ${ }^{\circ} \mathrm{C}$ & D93 & Min.60 & Min. 93 & $>116$ & $>116$ & $>116$ \\
\hline 3 & Cloud point, ${ }^{\circ} \mathrm{C}$ & D2500 & Max.+5 & Report & $<-10$ & +5 & -4 \\
\hline 4 & $\begin{array}{l}\text { Kinematic viscosity } \\
\text { at } 40^{\circ} \mathrm{C}, \mathrm{mm}^{2} / \mathrm{sec}\end{array}$ & D445 & $1.9-6.0$ & $1.9-6$ & 16.34 & 6.52 & 11.67 \\
\hline
\end{tabular}

\section{Engine Performance Testing}

Engine performance was measured in terms of brake power, brake torque and brake specific fuel consumption. In this section the engine performance of standard diesel fuel was compared with all blends.

The brake torque or engine torque obtained at different engine speed were shown in the Figure -3 . below for all tested fuel samples.
The fig. 3 shows that the engine torque of $\mathrm{B} 0$ fuel is higher than that of the B20 JB, B20 CB and B20 JCB fuels. The maximum torque was recorded at $1800 \mathrm{rpm}$, and it was $133.5 \mathrm{Nm}, 130 \mathrm{Nm}, 127.5$, and $129 \mathrm{Nm}$ for B0, B20 JB, $\mathrm{B} 20 \mathrm{CB}$ and $\mathrm{B} 20 \mathrm{JCB}$ respectively. The average torque reduction for $\mathrm{B} 20 \mathrm{JB}, \mathrm{B} 20 \mathrm{CB}$ and $\mathrm{B} 20 \mathrm{JCB}$ as compared to B0 was $2.62 \%, 4.49 \%$, and $3.37 \%$ respectively.

The brake power founded relative to the engine speed for all tested fuel samples are shown in the fig.4 below. 


\section{International Journal of Engineering Applied Sciences and Technology, 2019 \\ Vol. 4, Issue 3, ISSN No. 2455-2143, Pages 75-80 \\ Published Online July 2019 in IJEAST (http://www.ijeast.com)}

From fig.4 it is possible to say that the trend of the curves is almost similar. But the power output from diesel fuel (B0) is higher than of all others. It can be seen that the maximum brake power of the engine was recorded at $3500 \mathrm{rpm}$, and it was $42.5 \mathrm{~kW}, 41.8 \mathrm{~kW}, 40.4 \mathrm{~kW}$, and $41.2 \mathrm{~kW}$ for B0, B20 $\mathrm{JB}, \mathrm{B} 20 \mathrm{CB}$, and B20 JCB respectively. The reason for the lower brake power of biodiesels compared to diesel can be attributed to their lower calorific values and higher viscosities. Both the calorific value and viscosity have an effect on the combustion. Additionally, uneven combustion characteristics of biodiesel fuel decreased the engine brake power. Furthermore, it is seen that the average brake power reduction for $\mathrm{B} 20 \mathrm{JB}, \mathrm{B} 20 \mathrm{CB}$, and $\mathrm{B} 20 \mathrm{JCB}$ in compared to $\mathrm{B} 0$ fuel is $1.65 \%, 4.94 \%$ and $3.06 \%$, respectively.

The brake specific fuel consumption (Bsfc) of the engine at each engine speed was shown in the Fig. 5 for all tested fuel samples.

From the fig. 5 the curve shows the same trends for all tested sample of fuels. That the brake specific fuel consumption rate is higher at low speed increases a little for medium speeds and increases more at high speeds. From the results, the average brake specific fuel consumption (Bsfc) of $\mathrm{B} 0$, $\mathrm{B} 20 \mathrm{JB}, \mathrm{B} 20 \mathrm{CB}$, and B20 JCB is $330 \mathrm{~g} / \mathrm{kWh}, 347 \mathrm{~g} / \mathrm{kWh}$, $364 \mathrm{~g} / \mathrm{kWh}$, and $353 \mathrm{~g} / \mathrm{kWh}$, respectively. The reason for the higher Bsfc of biodiesels can be attributed to the combined effects of the relative fuel density, viscosity and heating value of the blends. Since, the brake specific fuel consumption (Bsfc) of diesel engine depends on the relationship among volumetric fuel injection system, fuel density, viscosity and lower heating value. Biodiesel fuel is delivered into the engine on a volumetric basis per stroke; thus, larger quantities of biodiesel are fed into the engine. Therefore, to produce the same power, more biodiesel fuel is needed because biodiesel has a lower calorific value compared to diesel fuel. Compared to $\mathrm{B} 0$ the average brake specific fuel consumption increment for B20 JB, B20 CB, and $\mathrm{B} 20 \mathrm{JCB}$ is $4.89 \%, 9.34 \%$, and $6.51 \%$ respectively.

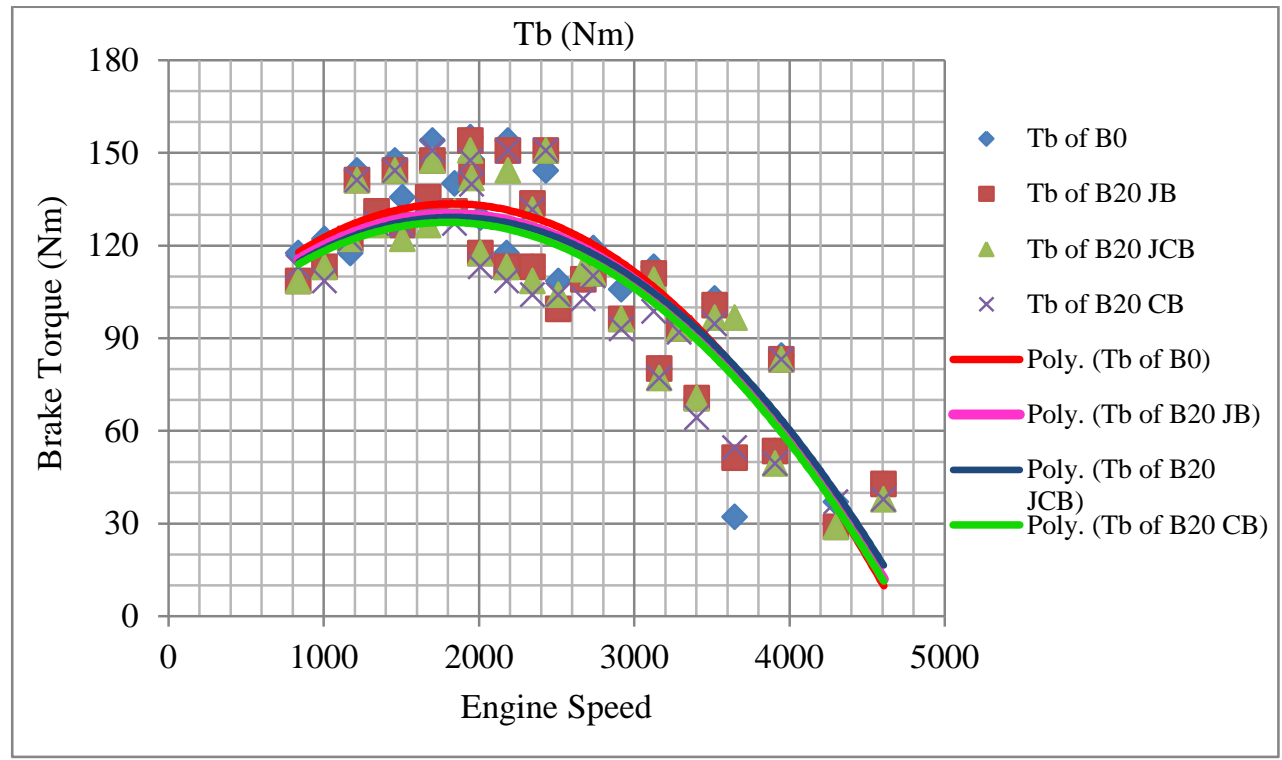

Fig.3. Comparison of brake torque vs. Engine speed of all tested fuel samples.

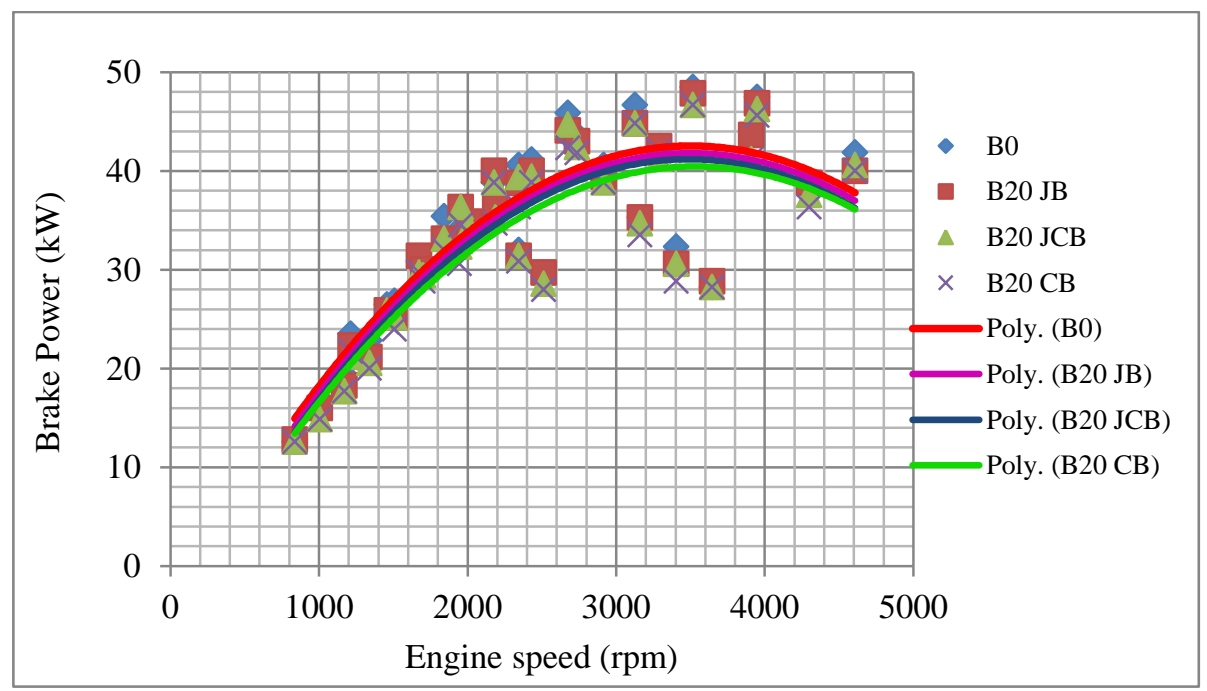

Fig.4. Comparison of brake power vs. engine speed for all tested fuel samples. 


\section{International Journal of Engineering Applied Sciences and Technology, 2019 \\ Vol. 4, Issue 3, ISSN No. 2455-2143, Pages 75-80 \\ Published Online July 2019 in IJEAST (http://www.ijeast.com)}

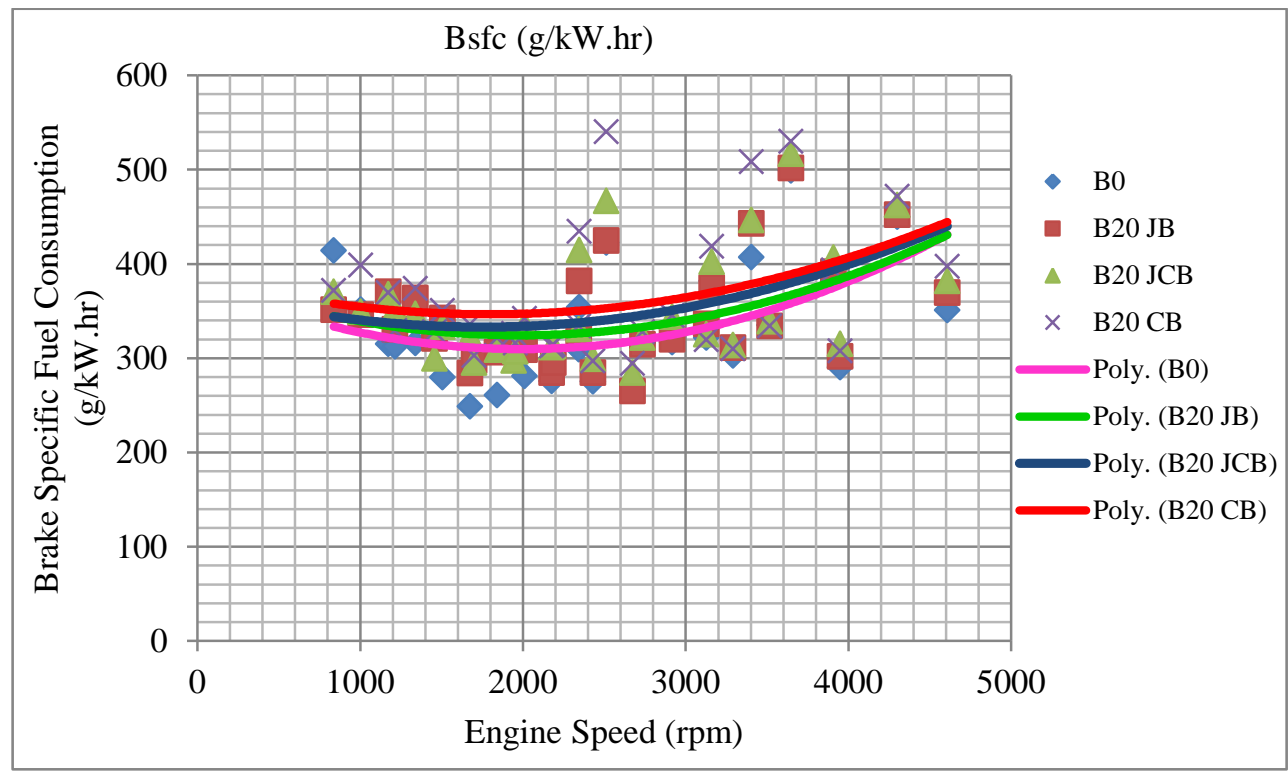

Fig.5. Comparison of Bsfc vs. engine speed for tested fuel samples

\section{CONCLUSIONS}

The overall studies based on extraction, production of biodiesel, characterization, and engine performance test of Jatropha, castor, and mixture of castor and Jatropha biodiesel blends were carried out.

Biodiesel produced from Castor and Jatropha oil is completely miscible with each other and also with diesel fuel thus allowing the use of blends of diesel and biodiesel in any percentage. The characteristics of biodiesel produced from Castor oil show the higher viscosity and density than those of Jatropha oil. The mixture of Jatropha and Castor oil biodiesel gives the lesser viscosity and density. The flash points of Castor, Jatropha and the blend of both biodiesel were within the standard. The properties of biodiesel from Jatropha oil at low temperatures are poorer than those of Castor oil. The biodiesel blends of Castor oil with Jatropha cause to the improvement for the operation in cold weather. Generally, biodiesel produced from Castor and Jatropha oil is completely miscible with each other and also with diesel fuel. In addition, it used to improve the high viscosity and density of castor biodiesel and improve the Jatropha biodiesel properties in cold weather operation. Compared to Castor biodiesel blend (B20 CB) the mixture of Jatropha and Castor biodiesel blend (B20 JCB) reflect good performance characteristic in diesel engine. From the experimental investigations the mixture of Jatropha and Castor biodiesel blend (B20 JCB) can be used as an alternative source of fuel in the future.

\section{ACKNOWLEDGMENT}

I would like to thank Melkassa Agricultural Research Center for its support by providing the Castor and Jatropha seed used for this research. My gratitude would also extend to Bako Agricultural Mechanization Research Center for its providing the mechanical pressing machine for castor seed. I am strongly indebted to ASTU, Chemistry Department Laboratory technical staffs and ASTU, Department of Mechanical and Vehicle Engineering staffs for their support.

\section{REFERENCES}

[1] Agarwal, A. K. (2007). Biofuels (alcohols and biodiesel) applications as fuels for internal combustion engines. Progress in energy and combustion science, 33(3), pp.233-271.

[2] Akhtar, T. (2011). Synthesis of biodiesel from triglyceride oil (Master's thesis, University of Stavanger, Norway).

[3] Mekhilef, S., Siga, S., \& Saidur, R. (2011). A review on palm oil biodiesel as a source of renewable fuel Renewable and Sustainable Energy Reviews, 15(4), pp.1937-1949.

[4] Benjumea, P., Agudelo, J., \& Agudelo, A. (2008). Basic properties of palm oil biodiesel-diesel blends. Fuel, 87(10), pp. 2069-2075.

[5] Haseeb, A. S. M. A., Sia, S. Y., Fazal, M. A., \& Masjuki, H. H. (2010). Effect of temperature on tribological properties of palm biodiesel. Energy, 35(3), pp.1460-1464.

[6] Akanawa, T. T., Moges, H. G., Babu, R., \& Bisrat, D. (2014). Castor Seed from Melkasa Agricultural Research Centre, East Showa, Ethiopia and it's biodiesel performance in Four Stroke Diesel Engine. International Journal of Renewable Energy Development, 3(2), pp.99.

[7] Firew Deresse at al. (2016), 'The performance evaluation of diethyl-ether (DEE) additive with Diesel blends using Diesel Engine test rig', International Journal of Scientific \& Engineering Research, Volume 7, Issue 6, pp 23-29.

[8] Tiku Tesfahun (2015). 'Performance Evaluation of Biodiesel Produced from Avocado Seed in Diesel Engine.', unpublished Masters Thessis, Adama science and Technology University, pp.63.

[9] Derege Dagne et al. (2015), 'Production of biodesel from Argemone Mexicana seed oil and testing its performance in diesel engine', unpublished Masters 


\section{International Journal of Engineering Applied Sciences and Technology, 2019 \\ Vol. 4, Issue 3, ISSN No. 2455-2143, Pages 75-80 \\ Published Online July 2019 in IJEAST (http://www.ijeast.com)}

Thessis, Adama science and Technology University, pp.56.

[10] Kumar, K., \& Sharma, M. P. (2016). Performance and emission characteristics of a diesel engine fuelled with biodiesel blends. International Journal of Renewable Energy Research (IJRER), 6(2), pp.658-662.

[11] Mofijur, M., Masjuki, H. H., Kalam, M. A., \& Atabani, A. E. (2013). Evaluation of biodiesel blending, engine performance and emissions characteristics of Jatropha curcas methyl ester: Malaysian perspective. Energy, 55, pp.879-887.

[12] Valente, O. S., Da Silva, M. J., Pasa, V. M. D., Belchior, C. R. P., \& Sodré, J. R. (2010). Fuel consumption and emissions from a diesel power generator fuelled with castor oil and soybean biodiesel. Fuel, 89(12), pp.3637-3642.

[13] Gopal, K. N., \& Karupparaj, R. T. (2015). Effect of pongamia biodiesel on emission and combustion characteristics of DI compression ignition engine. Ain Shams Engineering Journal, 6(1), pp.297-305.

[14] Salvi, B. L., \& Jindal, S. (2013). A comparative study of engine performance and exhaust emissions characteristics of linseed oil biodiesel blends with diesel fuel in a direct injection diesel engine. Journal of The Institution of Engineers (India): Series C, 94(1), pp.1-8.

[15] Özcanli, M., Serin, H., Saribiyik, O. Y., Aydin, K., \& Serin, S. (2012). Performance and emission studies of castor bean (Ricinus Communis) oil biodiesel and its blends with diesel fuel. Energy Sources, Part A: Recovery, Utilization, and Environmental Effects, 34(19), pp.1808-1814.

[16]Dishika. (2014). "Performance Evaluation and Emissions characteristics of a Compression Ignition Engine Using Castor oil based Biodesel, unpublished" Master's Thesis submitted to Thapar University, Patiala, pp.69.

[17] Kuthalingam, A. B., Asokan, G., Marta, V., Skryabin, I., \& Karuppiah, S. (2013). Performance and emission characteristics of double biodiesel blends with diesel. Thermal Science, 17(1), pp.255-262.

[18]Rao, V. (2015). Dual Biodiesel-Diesel blends Performance on Diesel engine as an Alternative Fuel.

[19] Srithar, K., Balasubramanian, K. A., Pavendan, V., \& Kumar, B. A. (2017). Experimental investigations on mixing of two biodiesels blended with diesel as alternative fuel for diesel engines. Journal of King Saud University-Engineering Sciences, 29(1), pp.50-56.

[20] Nalgundwar, A., Paul, B., \& Sharma, S. K. (2016). Comparison of performance and emissions characteristics of DI CI engine fueled with dual biodiesel blends of palm and jatropha. Fuel, 173, pp.172-179.

[21] Kini, K., Dsouza, H. S., \& Kumar, N. S. (2016). Investigation of Properties of Different Blends of Castor and Pongamia Biodiesels and Their Performance in a Compression Ignition Engine. Energy and Power, 6(1A), pp.8-14.

[22] Mengesha Kassahun, B., Balcha, M., Damtew, Z., BIsrat, D., Asaminew, G., Tadese, S., \& Abate, S.
(2016). Fatty acid and biodiesel characteristics Ethiopian Jatropha (Jatropha curcas L.) provenances. International Journal of Advanced Biological and Biomedical Research, 4(1), pp.15-31. 